\title{
Neural Crest Cell
}

National Cancer Institute

\section{Source}

National Cancer Institute. Neural Crest Cell. NCI Thesaurus. Code C33937.

An embryonic cell that separates from the neural plate during formation of the neural

tube and migrates to give several different lineages of adult cells: the spinal and

autonomic ganglia, the glial cells of the peripheral nervous system, and nonneuronal cells,

such as chromaffin cells, melanocytes and some haemopoietic cells. 